\title{
高 $\mathrm{C}$ 高 $\mathrm{Cr}$ ダイス鋼 (SKD 1) の諸性質におよぼす
}

\section{$\mathrm{W}, \mathrm{Mo}$ おび $\mathrm{V}$ の影響}

\author{
小柴 定 雄**. 清 永 欣 吾***
}

\author{
Effect of W, Mo and V on the Various Properties of High-C, \\ High-Cr Die Steel (SKD 1)
}

\author{
Sadao Koshiba and Kingo Kiyonaga
}

\section{Synopsis:}

High-C, high-Cr cold die steel (SKD 1) is widely used for punching dies and appreciated as an abrasion-resisting and a material non-deformable due to heat treatment. Lately, necessity for promoting productivity of motor or transformer core materials due to increased demands needs to further improve die life of this steel. Based on the above reason, the effect of $W$, Mo and $V$ was investigated on such various properties of SKD 1, which contained the behavior of hardness, micro-structure, hardenability, distortion ratio due to heat treatment, toughness and wear resistance. Main results obtained were as follows:

(1) By addition of Mo and W to SKD 1, as-quenched hardness was increased at lower temperatures and decreased at higher temperatures. On the other hand, the addition of $\mathrm{V}$ showed the inverse effect.

(2) The addition of $\mathrm{W}$, Mo and $\mathrm{V}$ increased the resistance to temper-softening of quenched specimens. This effect was in the following order: $\mathrm{Mo}>\mathrm{W}>\mathrm{V}$.

(3) Hardenability of SKD 1 was improved by addition of these alloying elements, but the effect of Mo was much remarkable.

(4) V-contained specimens were comparatively insensitive to changes of distortion ratios due to quenching temperature.

(5) Decomposition of retained austenite due to tempering appeared in one or two stages, influenced by chemical composition of specimens. By observation on the dilatation of specimens, it was deduced that the addition of $\mathrm{W}$ developed the decomposition of retained austenite in the first stage of tempering, and the combined addition of Mo and $\mathrm{V}$ depressed this tendency.

(6) Wear resistance was improved by addition of W, Mo and V, but especially the effect was the strongest with $\mathrm{W}$ and the weakest with Mo.

\section{I. 緒言}

高 C高 Cr 鋼（SKD 1) は打抜型材として広く使用世 られ，烍入組織中に存在する多量の硬い炭化物によつて 厚れた耐摩耗性を示し，また熱処理による変形の僅少な ことは周知のことである. 最近変圧器コアあるいはモー ターコアの需要が増加するにつれて, 本鋼よりさらに耐 摩耗性が良く，したがつて型寿命の長い打抜型用鋼が要 望されている.かかる目的に沿うものとして従来から高 $\mathrm{C}$ 高 $\mathrm{Cr}$ 系ダイス鋼におよぼす $\mathrm{V}, \mathrm{Mo}, \mathrm{W}, \mathrm{Co}, \mathrm{Si}$ どの単独添加の影響についてかなり研究が行なわれてい るようであるが1) 全般的な性能について検討したもの 少なく,かならずしも十分な結論は与えられていない。 本研究は本鋼の諸性質におよぼす W, Mo および V
の単独添加の効果ならびに Mo および V の組合せ添 加の影響を明らかにしたもので，これらの鋼種の熱処理 特性, 焼入性, 変形萃, 䩳性ならびに酎摩耗性などにつ いて嚇した結果を述べる。

\section{II. 供試材および実験方法}

（1）供試材の条件

各試作鋼は $50 \mathrm{~kg}$ 高周波师によつて吹製し, いずれ も $30 \mathrm{~kg}$ 鋼塊に鋳造した。これらを $12 \mathrm{~mm} \oint, 20 \mathrm{~mm}$

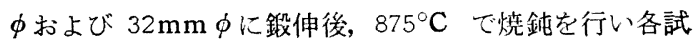

* 昭和 34 年 11 月本会㸌演会にて発表

** 日立金属工業株式会社 安来工場工博

*** 日立金属工業株式会社 安来工場 
Table 1. Chemical composition of test specimens.

\begin{tabular}{|c|c|c|c|c|c|c|c|c|c|c|c|c|}
\hline $\begin{array}{c}\text { No. of } \\
\text { specimens }\end{array}$ & C & Si & $\mathrm{Mn}$ & $\mathbf{P}$ & $\mathbf{S}$ & $\mathrm{Ni}$ & $\mathrm{Cr}$ & W & Mo & V & $\mathrm{Cu}$ & $\begin{array}{c}\text { Annealed } \\
\text { hardness } \\
\left(\mathrm{H}_{\mathrm{B}}\right)\end{array}$ \\
\hline $\mathrm{C}$ & $2 \cdot 38$ & 0.37 & 0.55 & 0.019 & 0.011 & 0.06 & $11 \cdot 58$ & - & - & - & 0.02 & 225 \\
\hline W & $2 \cdot 24$ & 0.23 & 0.47 & 0.014 & 0.006 & 0.07 & $10 \cdot 72$ & 0.82 & - & - & 0.02 & 235 \\
\hline M & $2 \cdot 28$ & 0.29 & 0.45 & $0 \cdot 018$ & 0.010 & 0.03 & $10 \cdot 77$ & - & $1 \cdot 04$ & - & 0.02 & 262 \\
\hline V & $2 \cdot 34$ & $0 \cdot 26$ & 0.45 & 0.021 & 0.007 & 0.02 & $11 \cdot 34$ & - & - & 0.83 & 0.03 & 237 \\
\hline $\mathrm{MV}-1$ & $2 \cdot 32$ & 0.28 & 0.43 & 0.014 & 0.009 & 0.07 & $10 \cdot 17$ & - & 0.95 & 0.46 & 0.04 & 262 \\
\hline $\mathrm{MV}-2$ & $2 \cdot 14$ & 0.25 & 0.39 & 0.016 & 0.010 & 0.05 & $11 \cdot 43$ & - & $1 \cdot 55$ & 0.82 & 0.04 & 231 \\
\hline
\end{tabular}

験材を削出した. Table 1 に供試材の化学成分を示す。 焼鈍硬度は M および MV-1 がやや高く，他は大差が ない，共晶炭化物の大きさは $\mathrm{W} ， \mathrm{~V}$ の添加によつて幾 分微細化する傾向が恋められるが，試料数が少ないので 明確てはない。

\section{(2) 実験方法}

（a）変態点の測定：本多式熱膨脹計を用いて最高 加熱温度 $1000^{\circ} \mathrm{C}$ における加熱および泠却変態点を測定 した.

(b) 熱処理硬度およぴ 組織の観察： $12 \times 12 \times 10$ $\mathrm{mm}$ の試料を $850 \sim 1050^{\circ} \mathrm{C}$ の各温度に $20 \mathrm{mn}$ 保持後油 焼入を行い，焼入温度と硬度の関係を調査した。つきに これらの焼入試料を $100 \sim 750^{\circ} \mathrm{C}$ に各 $1 \mathrm{~h}$ 繰返焼戻を行 ない，その焼戻軟化状況を調査し，あわせて上記処理に おけるミクロ組織を観察した。

（c）焼入性試験: $12 \times 12 \times 10 \mathrm{~mm}$ の試料を所定 の温度より各種の泠却速度によつて冷却し, その半冷時 間と硬度の関釈を求めた4). 半冷時間は試料の中央に $3 \phi \times 3 \mathrm{~mm}$ の孔をあ，その中に熱電 対を挿入して冷 却時の時間一温度曲線を求め, 焼入温度の $1 / 2$ の温度ま で下がるに要する時間を求めた.この際のオーステナイ ト化温度は各鋼の最高焼入硬度をうるような温度を採用 した.

（d）熱処理变形: $12 \mathrm{~mm} \oint$ の焼鈍材より $8 \phi \times 80$ $\mathrm{mm} \boldsymbol{l}$ の試料を作製し，これの焼入および焼戻による寸 度変化をマイクロメーターによつて測定した. 焼入温度 はいずれも $950,1000,1050^{\circ} \mathrm{C}$ の 3 種類,焼戻は $750^{\circ} \mathrm{C}$ まで各温度に $1 \mathrm{~h}$ 䆆返烧戻を行なつた。なお変形种とし ては焼入前の寸度に对寸る熱処理後の寸度変化の百分比 をむつて示した。

(e ）靶性試験： $5 \phi \times 70 \mathrm{~mm}$ の抗折試験片を1000 ${ }^{\circ} \mathrm{C}$ より油焼入し, 各 $200 \sim 350^{\circ} \mathrm{C}$ で $1 \mathrm{~h}$ 焼戻した場合 の抗折荷重および破壊時の最大撓み量を測定した・各熱 処理条件における試験片籄数は 3 コ, 結果はその平均値 をもつて示した.この方法はスパンの長さ $50 \mathrm{~mm}$ の 2 点によつて支持された試験片の中央に静荷重を加え, 予
圧 $10 \mathrm{~kg}$ をかけた後の堯みをダイヤルゲージによつて睍 定する.したがつて撓み量は荷重 $10 \mathrm{~kg}$ より破壊時ま での㩑み量となる。

(f) 年耗試験： $32 \mathrm{~mm} \phi$ 材より $30 \phi \times 16 \phi \times 8$ $\mathrm{mm}$ のリング試料を削出し，これらを 950,975 およひ $1000^{\circ} \mathrm{C}$ で各 $30 \mathrm{mn}$ 加熱保持後油冷し, $200 \sim 300^{\circ} \mathrm{C} \tau$ HRC 60〜61 の硬度になるように焼戻した. 熱処理後; 表面仕上を行ない，同鋼種，同熱処理の試料同志を組合 わせて西原式摩耗試験機により試験した。この際の圧缩 荷重は $60 \mathrm{~kg}$, 最大圧縮応力 $60.5 \mathrm{~kg} / \mathrm{mm}^{2}$, 上部試料 の回転速度は $65 \mathrm{~m} / \mathrm{mn}$, 下部試料は $73 \mathrm{~m} / \mathrm{mn}$ の乾燥磨 耗で，したがつて上部試料は下部に対しー12:3\%の滑り 率をもつて摩耗する。

\section{III. 実験結果およびその考察}

\section{（1）変態点の生起状況}

変態点の測定結果を Table 2 に示す. 従来の知見に よればCの増加は $\mathrm{Ac}_{1}$ の低下, $\mathrm{Cr}$ の 增加は $\mathrm{Ac}_{1}$ の 上昇を来す，W，Mo，V はいずれも $r$ に対するCの数 解度を減ずるが $\mathrm{Ac}_{1}$ に対してはほとんぞ影樴を与えめ とされている・ただし Jones(5) によれば Mo は Ac を僅かに上昇するといわれる. 本研究に使用した試料浊 Cおよび Crにおいてかなりの差があるために他の元 の影響を明暸に知ることは困難であるが, Table 2 上り つぎのことが知られる.

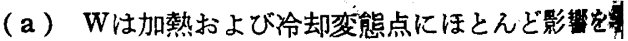

Table 2. Transformation temperature of specimens $\left({ }^{\circ} \mathrm{C}\right)$

\begin{tabular}{c|c|c|c}
\hline $\begin{array}{c}\text { No. of } \\
\text { specimens }\end{array}$ & $\begin{array}{c}\text { On heating } \\
\left(5^{\circ} \mathbf{C} / \mathbf{m n}\right)\end{array}$ & \multicolumn{2}{|c}{ On cooling } \\
\cline { 3 - 4 } & & $\begin{array}{c}\text { Furnace cool. } \\
\left(5^{\circ} \mathbf{C} / \mathbf{m n}\right)\end{array}$ & Air cool. \\
\hline C & $797 \sim 826$ & $734 \sim 713$ & $170 \sim$ \\
W & $775 \sim 815$ & $735 \sim 705$ & $162 \sim$ \\
M & $817 \sim 848$ & $745 \sim 725$ & $165 \sim$ \\
V & $790 \sim 815$ & $740 \sim 723$ & $131 \sim$ \\
M V-1 & $785 \sim 821$ & $714 \sim 690$ & $155 \sim$ \\
M V-2 & $809 \sim 837$ & $400 \sim 340$ & $168 \sim$ \\
\hline
\end{tabular}


にない。この結果は小柴, 永島”の結果と一致する。

（b）Mo は加熱変熊点を上昇するようである.

（c）Mo および V の組合せ添加により冷却变態点 はいちじるしく低下する。

(2) 烧入硬度

Fig. 1 に油冷 および空冷の場 合の焼入温度と 硬度の関係を示 した.Wおよび Mo の添加泜 认焼入温度にお 壮る硬度を上昇 し, 高い焼入温 度側の硬度を低 下させるが, 一

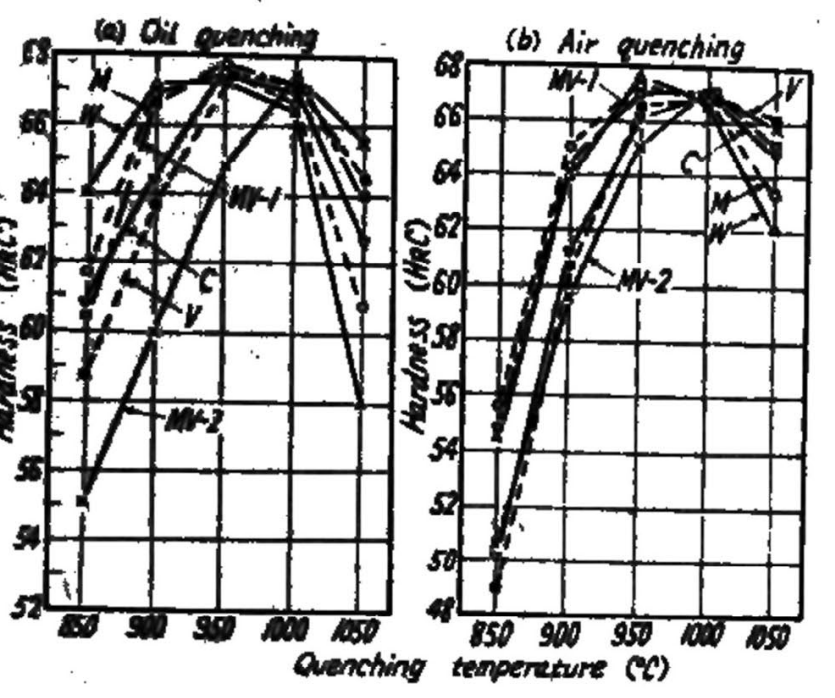

Fig. 1. Relation between quenching temperature and hardness.
方Vの添加はその逆の傾向を示し高い温度側の硬度を上 㫒させる. また Mo と V の組合せ添加により高い焼 入温度における硬度が増加している。もちろん，このよ うな焼入温度と硬度の関係はCおよび $\mathrm{Cr}$ 量にきわめて 大きな影響をうけるので，上記の傾向は Mo あるいは Vのみの効果であるとは判定しがたい，例えばM，W 試 料は Cr 加低く，V，MV-2 は Cr がやや堌加している
西沢, 村井等の研究8)によれば, 高 $\mathrm{C}$ 高 $\mathrm{Cr}$ 鋼中の炭化物 は少量の W あるいは Mo の添加によつていちじるし く影響される.すなわち本鋼中の炭化物は $\mathrm{M}_{7} \mathrm{C}_{8}$ 型炭化 物のみが存在するがWおよび Mo が添加されれば $\mathrm{M}_{23} \mathrm{C}_{6}$ 型炭化物が主要な宸化物となり， $\mathbf{M}_{28} \mathrm{C}_{6}$ は $\mathbf{M}_{7} \mathrm{C}_{\mathbf{3}}$ より も $\gamma$ 中に溶け込み易いので7)，上記のような焼入硬度特 性を示すと考えられる. 一方 V注主として MC 型炭化物 を形成し，これが $\mathbf{M}_{7} \mathbf{C}_{9}$ 型炭化物より溶け远み難く, し たがのて高温からの焼入による残留オーステナイトの生 成を抑制するからであろう．Fig.2亿試料の焼入時のミ クロ組織を示すが，合金元素の添加により炭化物の微細 化が進行していることがかかる.なおこれらの試料にお いては無腐食で認められる炭化物注はとえど検出できな かつた.

(3) 焼戻硬度

前項の焼入硬度材料を用いて $100 \sim 750^{\circ} \mathrm{C}$ に綝返焼戻 を行なつた場合の焼戾温度と硬度の関係を Fig. 3 に示 す.ただし焼入温度はいずれも $1000^{\circ} \mathrm{C}$ の場合を示して ある.これら試料の焼㞔欧化状況は SKD 1 のそれとよ く類似しているが，合金元秦の添加によつて赖化抵抗は やや大となる. しかしその効果は Mo がもつとも強 く，WとVでは大差はないが，ややWの方が大きい上う である.

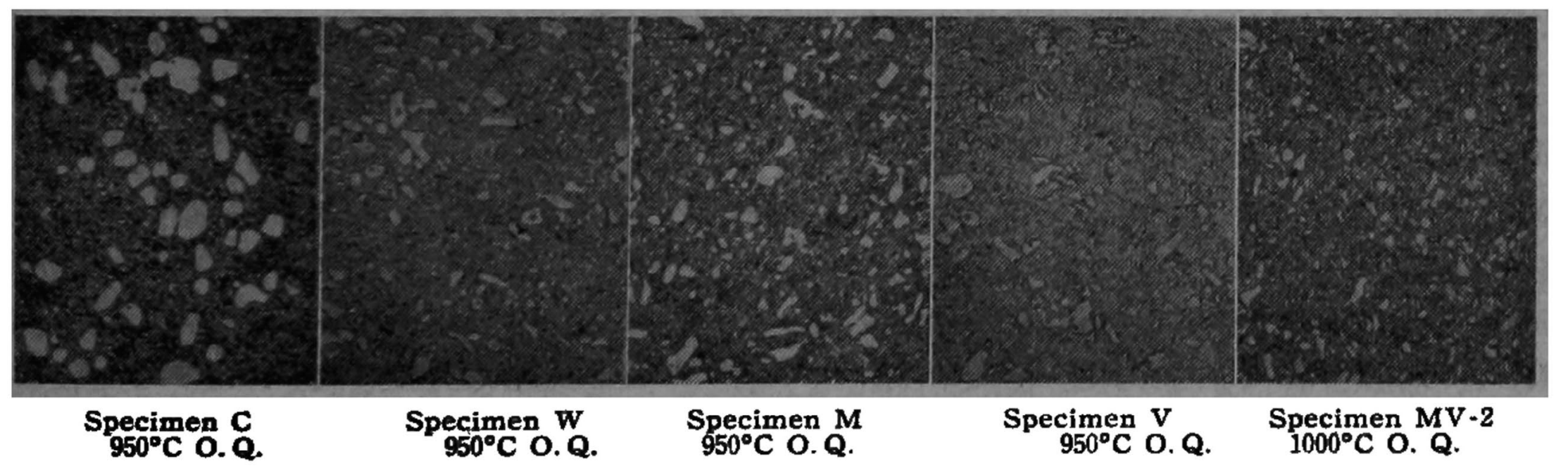

Fig. 2. As-quenched structures of specimens.

のでこれらの傾向は実際よりむむしろ強調されていると 考えられる.

空冷の場合も同様な傾向が認められる. MV-1 と C 試料を比較すれば，前者が厇い焼入温度にわたりつねに Cょりむ高い焼入硬度を示しているが，これは Mo とV の臭当な組合せによつて広い焼入温度範囲を与えること ができるであろうことを示唆している.すなわち Mo によつて低い焙入温度における硬度を，Vによつて高い 蟙入温度における硬度をそれぞれ上昇させるというので ある。

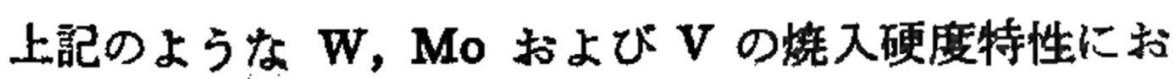
よほす影嗼は下钎のように説明するととができる，佐藤

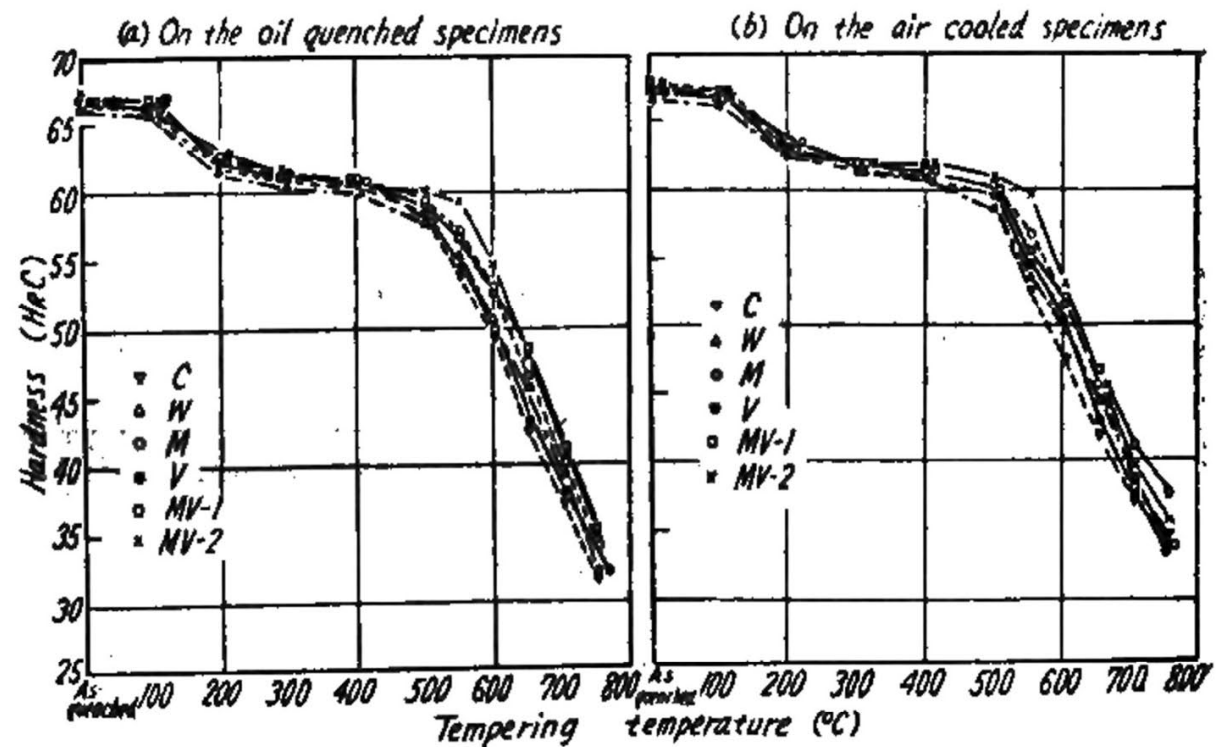

Fig. 3. Relation between tempering temperature and as-tempered hardness. 
（4）焼入性

各試料の焼入性を比較するために半冷時間と硬度の関 係を調査した結果允 Fig. 4 亿示す. 各試料のオーステ ナイト化温度はV 含有鋼が $1000^{\circ} \mathrm{C}$ ，その他は $950^{\circ} \mathrm{C}$ と した．本図に示すごとく合金元素の添加により娔入性は 増加するが，W， Vの効果は比較的小さく $\mathrm{Mo}$ はいちじ るしく焙入性を上昇させる。なた Mo と Vを同時に添加 した MV 系試料の㶿入性も良好である。この絬果治炭 素工具鋼 $(10 \circ \mathrm{C})$ の焼入性に就よぼす合金元秦添加の 影留を研究した R. E. Shoup ${ }^{\beta)}$ の結糡とよく一致して いる.

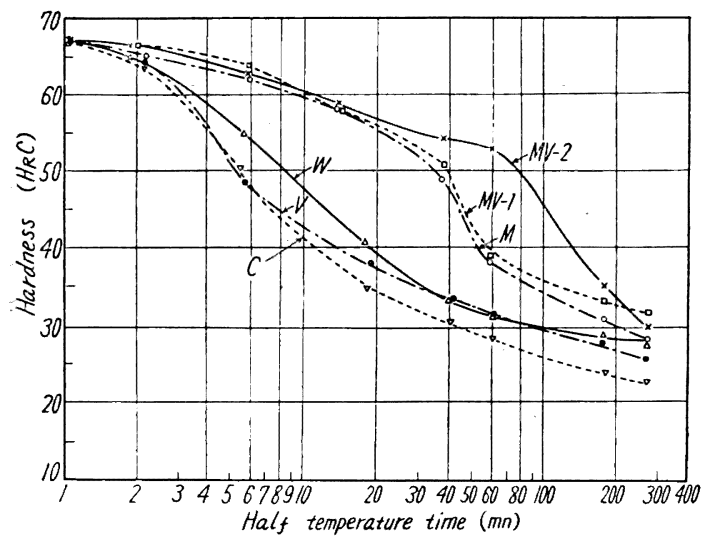

Fig. 4. Relation between half temperature time and hardness on continuous cooling.

（5）焼入温度と変形率 $8 \phi \times 80 \mathrm{~mm}$ の試料につ いて各試料の焼入温度と直 径変化萃 $\alpha(d)$ 抢よび長さ 変化率 $\alpha(l)$ との関係を示 したのが Fig. 5 である. 焼入温度の上昇に伴い直径 は減少し, $1050^{\circ} \mathrm{C}$ 焼入で はほとんどの試料が原寸に 対して収縮を示している. 比較的この傾向の少ないの : $\mathrm{V}, \mathrm{MV}$ 系のV含有試料 で, 高い焼入温度で硬度低 下の少ない，すなわち残留

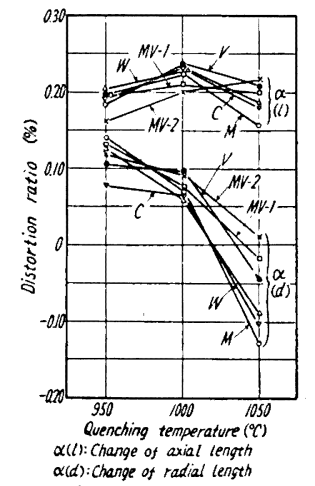

Fig. 5. Change of distortion ratio with different quenching temperatures.
オーステナイトの生成傾向の少ない陚料である.これら の試料においては烍入温度の相逗による变形率の变動が 僅少となる。

一方長さ変化率は焼入温度が $950 \sim 1000^{\circ} \mathrm{C}$ に上昇す ることによつて增加し, $1000^{\circ} \mathrm{C} よ り ~ 1050^{\circ} \mathrm{C}$ に上昇す
れば逆に減少を示す傾向がある。しかし MV 系試料さ は $1050^{\circ} \mathrm{C}$ にふいてもなお膨脹の傾向を示している.

上記のごとく Mo および W は焼入温度の変動によ る膨脹ないしは収縮を加速し，Vは鈍感にする傾向があ る.しかし熱処理変形の絶対量は邀当な焼入温度を遂へ ばかかる合金元素の添加によつてほとんど相違しない。

直径上舆さの変形傾向の異なるのは J. Frehser" $の$ 研究が示与ように鍛造による炭化物の異方性によつて理 解できる。本研究鋼の加工乘は約 $98 \%$ であり，変形㑯 向におよぼす炭化物の異方性の影穼はかなり大きいと思 われる。

(6) 情厌温度と変形率

前項 $01000^{\circ} \mathrm{C}$ 油焼 入試料を $100 \sim 750^{\circ} \mathrm{C}$ に $1 \mathrm{~h}$ 筧㕄した場合の 原寸に対与る変形率の 変化の模㥞在 Fig. 6 に示す.焼戻の進行に したがつて直径ならび に長さ注次第に収䕓す るが 300 C および500 ${ }^{\circ} \mathrm{C}$ 近辺で膨脹在示し ている、試料によつて このような2段の膨脹 を示すものと，第 1 段 の膨脹を示さず第 2 段

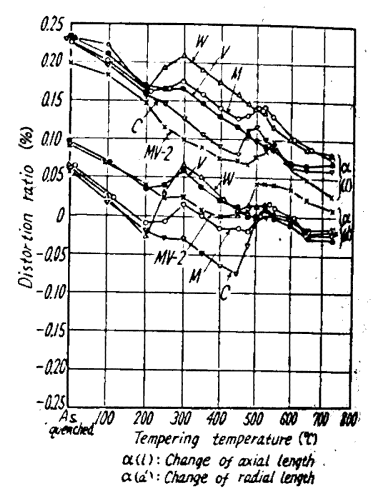

Fig. 6. Change of distortion ratio with different tempering temperatures.
の膨脹のみを示すものとがある.C試料は第2 段が主体 で第1段の膨脹は僅かであるがWでは第 1 段の膨脹が主 体となつている．Ｍ試料およびV試料では两方現われる が，V の膨脹量は比較的少ない. MV-2 では第1段の 膨脹はほとんど消滅し，第2段の膨脹のみとなつてい る.これは $1000^{\circ} \mathrm{C}$ 烍入試料についての結果であるが, $950^{\circ} \mathrm{C}$ および $1050^{\circ} \mathrm{C}$ 焼入試料についてもやはり同様の 傾向があり（図省略）烧入温度が上昇するにしたがい単 に膨脹量の総和が大となるに過ぎない。

焼戻の際に生ずるこのような 2 段の膨脹は残留オース テナイトの分解が 2 段に分離して行なわれることを示才 ものと思われる. 実際の抜型材は高硬度を保有させるた めに焼厌は $200^{\circ} \mathrm{C}$ 付近の比較的低い焼戾温度を採用す るがこの場合 $300^{\circ} \mathrm{C}$ 付近の分解を伴う鋼種は使用時飞 時勃变形を起す可能性があり，したがつて第 1 段の分解 はできるだけない方が望ましい. 本研究の結果, 第 1 段 の分解に関しては焼入温度による分解機構の差よりむ成 分による差の方が大であるように思われる。いかなる成 
分の場合に $300^{\circ} \mathrm{C}$ 付近の分解が生じるかは明らかでは ないが， $\mathrm{Cr}$ 量が高く， C 量の比較的低い場合，文た V のごとく高温まで残留オーステナイトの生成を抑制する ような元素の添加はその安定性を增加せしめ，第1段の 分解を起り難くするものと思われる。一方Wの含有は第 1 段の分解を促進するようである.

\section{(7) 敪性試験}

抗折試験の結果を Fig. 7 に示す.この際，曲汸佃重 と撓みは破断にいたるまでほぼ直線的関係にあつたので 弾性限内に打汁る破壞と考えられる。 それゆえ，次式に よつて抗折力 $(p)$ 巷求的た。

$$
p=8 W L / \pi D^{3} \quad\left(\mathrm{~kg} / \mathrm{mm}^{2}\right)
$$

ここに $W$ : 破壊時の曲げ荷重 $(\mathrm{kg})$

$$
\begin{array}{lc}
L: \text { スパンの長さ } & (50 \mathrm{~mm}) \\
D: \text { 試料の径 } & (5 \cdot 0 \pm 2 / 100 \mathrm{~mm})
\end{array}
$$

Fig. 7 に示すごとく焼戻 温度の上昇にしたがつて硬 度は低下するにもかかわら ず抗折力および撓みはほと んど変化を示さず焼㞔温度 による一定の関係は認めら れない.ただし MV-2 は 抗折力，拯みともに大きく 他試料より鞂性のすぐれて いることがわかる。

\section{（8）耐摩耗性}

予備試験において $6 \times 10^{4}$

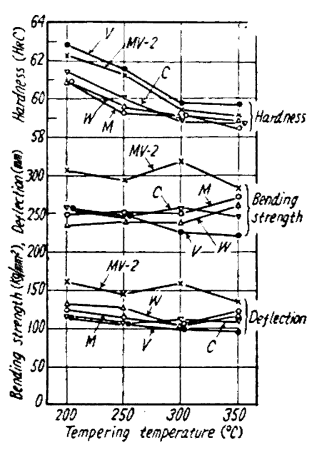

Fig. 7. Results of bend test.
回転後ほほ定常摩耗を示したので，試料をまず $6 \times 10^{4}$ 回転した後，その重量を科 量しこの值を基準値として $5 \times 10^{4}$ 回転おきの重量を 回転数総計 $31 \times 10^{4}$ 回転ま で科量した。試料はすべこ 同種同熱処理のもの同志を 組合せた.Fig. 8 はこの場 合の焼入温度と摩耗減量 (104回転における平均摩 耗減量）との関係を示す.

本図より明らかなように

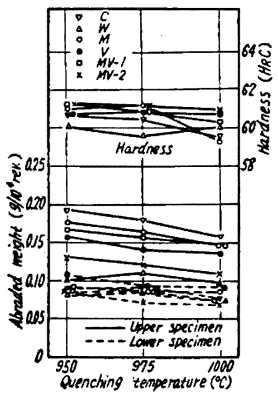

Fig. 8. Results of abrasion test.
焼入温度の上昇につれて試料の硬度は若于低下している にもかかわらず摩耗減量はむしろ減少している. 一般に 硬度の高いほど耐摩耗性の大きいのが普通であるが，こ の場合は逆の現象を示している.これは焼入温度の上昇 による残留オーステナイトの増加の結果硬度低下を示す
のであるが，本摩耗試験の条件では試料の線接触で局部 的にいちじるしい温度上昇と強加工が起り, 残留オース テナイトのマルテン化が進行するものと考えられる．高 温における焼㞔硬度は焼入温度の高いほど大きいので， 試験条件下では高温度で焼入れた試料汪ど耐摩耗性が大 きいのであろう。

Fig. 8 によれば下部試料は摩耗量が少なく，また試料 による摩耗量の差も少效いしかし上部試料では摩耗量 が大でしかも試料間の产が明膫に現われている。この差 は上下両試料の摩耗機棈の差に起因するもので上部試料 は引張忍力下に扔ける滑り摩耗であるのに対し，下部試 料は压䇮応力下に去ける滑り摩耗であるためであろう。

とも角, 上部試料によつて耐摩耗性の鋼種による差が判 定できるわけで，その結果，Wはいちじるしく耐摩耗性 を增加し，そのつぎがV， Mo の順となつているＶＶ Mo の組合せはこれら合金量の多い添ど耐摩耗性は向上 する・

試験終了後, 各試料の摩耗面の状沉ならびに組織を観 察した結果，Wの上部試料には比較的多くの酸化粉末が 象眼され，またミク口組織も炭化物がきわわて微細で, しかも多量に存在していた。これがW試料に耐摩耗性を 賦与した原因と考えられ，果してW自体の効果であるか 疑問である。

往来高 C 高 $\mathrm{Cr}$ 鋼の耐摩耗性が良いの多量の硬い $\mathrm{M}_{7} \mathrm{C}_{3}$ (Hv 2000 2500) ${ }^{10}$ ) 炭化物によるものといわれて いるが，Mo およびWの添加は比較的軟い $\mathrm{M}_{23} \mathrm{C}_{6}$ 禾の 炭化物（Hv 1500〜1800）吕）を生ずるのでむしろ耐摩耗 性は低下するとも考えられる。しかし本結果のように耐 摩耗性を良好にするのは炭化物総量の增加に起因する のであるかもしれない6).

摩耗試験結果:こよつて示される耐摩耗性法必らずしも 実用時の性啠を示すとは限らない。これ滑りとか転が り，圧力などの条件，表面酸化の条件，表面の加工硬化 などの相違によつて一条件の結果から他条件の場合を類 推することがほとんど不可能であるためである．実用条 件下の試験がもつとも望ましいわけであり，したがつて これら試料の耐摩耗性も抜型材としての実地試験の結果 によつて判定されるべきであろう.

\section{IV. 結言}

以上高 $\mathrm{C}$ 高 $\mathrm{Cr}$ ダイス鋼（(SKD 1）におよほすW, Mo, V および Mo, V の組合せ添加の影箩について 研究した結果を述べたが，これらを要䄪すると下記のご とくである。 
（1） Mo の添加は $\mathrm{Ac}_{1}$ を上昇し，Mo およびVの 組合せ添加によつて冷却变態点渣次低下する. W, V の変態点におよぼす影響は比較的小さい。

（2）Ｍo およびWの添加によつて低い焼入温度にお ける硬度を高为, 高い焼入温度からの焼入硬度を低下さ せる、Vはその逆の傾向を示す。また Mo拉よびVの適 当な配合は焼入温度範囲を拡げる可能性がある.

(3) W, Mo，V の添加によつて焼戾軟化抵抗は增 大する. その結果は $\mathrm{Mo}>\mathrm{W}>\mathrm{V}$ の順である.

（4）合金元素の添加により焼入性は增大するが，上 くに Mo の効果湿著である. Mo と V の組合せ添 加は燒入性をかなり改善する.

(5) 変形率試験の結果, $\mathrm{V}$ 含有鋼は焼入温度の变化 による変形率の変動が少ない，一方 Mo およびW を添 加した試料はこの変動が比較的大である.

（6）変形の絶対量は適正焼入温度を選えだ場合, 合 金元素量によつて余り変化しない。

（7）焼戻の場合, 試料の化学成分によつて残留才一 ステナイトの分解が1段あるいは2段に分れる. 第1 段 は約 $300^{\circ} \mathrm{C}$ ，第2段は約 $500^{\circ} \mathrm{C}$ に現わ机るが，Wは第 1 段の分解を促進するようである. 一方 Mo-V の組合 せ添加注第 1 段の分解を抑制する傾向がある。
（8）W, Mo, V の添加により靱性は余り変化しな い.しかし Mo-V の組合せ添加せる試料は抗折力なら びに破断時の撓みを増加した.

（9）W，Mo および V の添加によつて耐摩耗性は 改善されるが，その効果は $\mathrm{W}>\mathrm{V}>\mathrm{Mo}$ の順であうた。 Mo と V を同時に添加した場合も酎摩耗性を堌加す る. (昭和 34 年 12 月寄稿)

$$
\text { 交献 }
$$

1) W. H. Wills: Trans. Amer. Soc. Metals, 25 (1937), 1013.

2) J. P. Gill: Trans. A. S. S. T. 15 (1929), 387

3 ）小柴, 永島：鉄と鋼，39 (1953)，31

4) 小柴, 清永：鉄と鎆，44（1958），487

5) F. Rapatz (川崎訳): 特殊銅 136（昭14,8 コ口 ナ社)

6) 佐藤, 西沢, 村井: 鉄と鋼, 44 (1958)，565

7) W. Tofaute, C, Küttner, A. Büttinghaus: Arch. Eisenhüttenw. 9 (1936), 607

8) J. p. Gill, et al: Tool Steels (1946-ASM) 282

$9)$ J. Frehser, O. Lowitzer: Arch. Eisenhüttenw. 23(1953), 483.

10）佐藤，西沢，石原：日本金属学会誌”23 $(1959), 403$

\section{オーステナイト鋼の高温性質におよばす Ti の影響*}

\section{中川龍 一**.乙黒靖 男** \\ The Effect of Ti on High Temperature Properties of Austenitic Steel.}

\section{Ryuichi Nakagawa and Yasuo Otoguro}

\section{Synopsis:}

Following the previous report (Tetsu-to-Hagané 45, 1959, 11, p. 1276), the effect of Ti and $\mathrm{C}$ on the mechanical properties (such as creep rupture strength, tensile strength and aging hardness) and the microstructure of $18 \mathrm{Cr}-12 \mathrm{Ni}$ austenitic stainless steel containing $\mathrm{Ti}$ were studied.

The range of the $\mathrm{C}$ contents studied was from $0.06 \%$ to $0.49 \%$, and that of the $\mathrm{Ti}$ contents was from $0 \%$ to $1 \cdot 88 \%$.

With these steels, $\mathrm{TiC}$ and $\mathrm{Cr}_{23} \mathrm{C}_{6}$ precipitated during aging at $600,650,700$ and $750^{\circ} \mathrm{C}$. The aging hardness increased with increasing $C$ contents and decreased with increasing $\mathrm{Ti}$ contents.

When the Ti content was over four times as much as the $\mathrm{C}$ content, large granular TiC remained on grain boundaries. It seemed that this structure had a unfavorable effect on the mechanical properties.

* 昭和 34 年 11 月本会講演会にて発表 ** 金属材料技術研究所 